Acta vet. scand. 1968, 9, 105-111.

From the Department of Medicine, Veterinary College of Norway, Oslo.

\title{
THROMBOCYTES, LEUCOCYTES AND PACKED RED CELL VOLUME IN PIGLETS DURING THE FIRST TWO WEEKS OF LIFE
}

By

Halldis Lie

In connection with studies on thrombocytopenic purpura in baby pigs it was found necessary to know the variation in platelet number of normal piglets. Furthermore, it seemed to be of interest to see if this disorder is accompanied by any effects on the number of erythrocytes and leucocytes.

As far as we have been able to judge from the literature the information on normal numbers of the blood cells in piglets during the first 2 weeks is scanty, particularly for platelets, and in pigs of Norwegian breeds. Investigations for this purpose were therefore performed, the results of which are given in the present report.

\section{MATERIAL AND METHODS}

Blood samples for the purpose of platelet counting were obtained from 194 piglets. These belonged to 25 litters from 6 sows in whose sera no platelet or red cell antibodies could be demonstrated.

The same material, but 140 piglets only, was used for determination of leucocyte number and packed red cell volume (PCV).

The samples were taken with intervals from 1 to 3 days. The age of the litter when the last samples were taken varied from 9 to 15 days.

The piglets were kept indoors on concrete floors, but from the 2nd day of life they were allowed to root in earth sprinkled with $\mathrm{FeSO}_{4}$. An Osram "Siccatherm" lamp of $250 \mathrm{~W}$ placed $70 \mathrm{~cm}$ above the floor provided extra heat. 
The blood samples were taken by ear vein puncture with a sharp scalpel and studied within $5 \mathrm{hrs}$. To stop bleeding adhesive plaster was put on the ear.

Except for the samples taken at birth, all the samples were taken at $10.00-11.30$ a.m.

Counting of platelets. The counting method introduced by Nygaard (1933) was employed.

As anticoagulant was used EDTA $\left(\mathrm{C}_{10} \mathrm{H}_{14} \mathrm{~N}_{2} \mathrm{Na}_{2} \mathrm{O}_{8} \cdot 2 \mathrm{H}_{2} \mathrm{O}\right)$ as a $2 \%$ solution:

$\begin{array}{lrl}\text { EDTA } & 20 \mathrm{~g} \\ \mathrm{NaCl} \text { cryst. } & 5 \mathrm{~g} \\ \mathrm{NaOH}, 1 \mathrm{~N} & 35 \mathrm{ml} \\ \text { Aqua dest. ad } & 1000 \mathrm{ml}\end{array}$

By means of a $0.1 \mathrm{ml}$ pipette for thrombotest $0.05 \mathrm{ml}$ of blood was sucked from the ear vein and immediately mixed with $0.45 \mathrm{ml}$ of EDTA solution, $1.5 \mathrm{ml}$ of saline was then added. The samples were left for sedimentation in glass tubes $(8 \times 70 \mathrm{~mm})$ for $1 \mathrm{hr}$. With a pasteur pipette samples were taken from the centre of the red cell free part of the plasma and filled into a Bürker's counting chamber. After sedimentation in a moist chamber for $20 \mathrm{~min}$. countings were made in a light field microscope at $100 \times$ magnification.

The results are given as thousand platelets $/ \mathrm{mm}^{3}$.

Counting of leucocytes. The use of hemocytometers was found to be inconvenient because so many samples had to be taken at the same time. Therefore, $0.05 \mathrm{ml}$ of blood was sucked from the ear vein with the pipette for thrombotest and immediately mixed with $0.45 \mathrm{ml}$ of a solution composed of:

$\begin{array}{lcl}\text { Methyl violet } & 0.1 \mathrm{~g} \\ \text { Acet. acid conc. } & 1.0 \mathrm{~g} \\ \text { Aqua pur. } & 200 \mathrm{ml}\end{array}$

Countings were made in a Bürker's counting chamber.

The results are given as thousand leucocyte $/ \mathrm{mm}^{3}$.

Packed red cell volume (PCV). Heparinized capillar tubes were filled directly from the punctured vein. The tubes were closed by heating an end. After centrifugation for $8 \mathrm{~min}$. at 11,000 r.p.m. readings were made (the micro hematocrit method).

The results are given as volume \% red cells. 


\section{RESULTS}

Just after birth the piglets had a mean platelet count of 337 (range 190-575), which decreased during the first 2 days to 241 (range 175-375) followed by increasing numbers the next few days (Table 1, Fig. 1). The highest mean count, 578 (range 290775 ), was found on the 10th day, whereafter a slight decrease to 492 (range $300-900$ ) on the 15th day was observed.

The deviation of mean was large both within and between litters. But on the 2nd day, when the counts were lowest, a count below 190 was rare. In the period 9 th -15 th day counts below 280 were not observed.

The leucocyte number was highest the first $30 \mathrm{hrs}$. of life (Table 1, Fig. 1). During this period, however, there was as wide a range as from 3.6 to 46.3 .

Blood samples taken from 10 piglets, before they had been allowed to suck, had leucocyte counts ranging from 8.4 to 17.9. New samples were taken from 3 of these piglets $14 \mathrm{hrs}$. later. The counts, which at birth were $17.9,12.5$ and 9.2 , had increased to $18.1,15.9$ and 32.6 respectively.

T a ble 1. Platelet number, total leucocyte number and packed red cell volume $(\mathrm{PCV})$ in normal piglets during the first 15 days of life.

\begin{tabular}{|c|c|c|c|c|c|c|}
\hline $\begin{array}{l}\text { Days } \\
\text { after } \\
\text { birth }\end{array}$ & Platelets & $\begin{array}{l}\text { Obser- } \\
\text { vations }\end{array}$ & Leucocytes & $\begin{array}{l}\text { Obser- } \\
\text { vations }\end{array}$ & $\begin{array}{l}\text { Packed Cell } \\
\text { Volume }\end{array}$ & $\begin{array}{l}\text { Obser- } \\
\text { vations }\end{array}$ \\
\hline & $\underset{/ \mathrm{mm}^{3}}{\text { thousaud }} \mathrm{s}$ & & $\underset{/ \mathrm{mm}^{3}}{\text { thousand }} \mathrm{s}$ & & $\% \quad \mathbf{s}$ & \\
\hline 0 & $337 \pm 79$ & 102 & $16.9 \pm 6.8$ & 42 & $40.9 \pm 6.1$ & 36 \\
\hline 1 & $276 \pm 66$ & 141 & $15.3 \pm 6.2$ & 106 & $36.1 \pm 6.5$ & 95 \\
\hline 2 & $241 \pm 48$ & 131 & $9.4 \pm 3.8$ & 60 & $32.9 \pm 5.0$ & 67 \\
\hline 3 & $279 \pm 60$ & 125 & $10.2 \pm 3.1$ & 78 & $34.0 \pm 4.6$ & 58 \\
\hline 4 & $309 \pm 68$ & 89 & $11.8 \pm 3.3$ & 36 & $32.2 \pm 3.1$ & 44 \\
\hline 5 & $378 \pm 74$ & 78 & $11.6 \pm 3.5$ & 50 & $32.4 \pm 3.0$ & 37 \\
\hline 6 & $410 \pm 78$ & 90 & $10.2 \pm 3.5$ & 38 & $33.0 \pm 3.3$ & 29 \\
\hline 7 & $465 \pm 84$ & 95 & $10.8 \pm 3.6$ & 52 & $31.5 \pm 3.8$ & 41 \\
\hline 8 & $535 \pm 115$ & 75 & $9.1 \pm 2.9$ & 46 & $34.2 \pm 3.0$ & 38 \\
\hline 9 & $525 \pm 109$ & 103 & $8.0 \pm 1.9$ & 41 & $33.9 \pm 3.9$ & 56 \\
\hline 10 & $578 \pm 128$ & 76 & $9.4 \pm 3.1$ & 67 & $34.4 \pm 3.1$ & 39 \\
\hline 11 & $495 \pm 96$ & 76 & $8.3 \pm 2.5$ & 26 & $35.0 \pm 5.2$ & 33 \\
\hline 12 & $553 \pm 113$ & 51 & $8.6 \pm 3.0$ & 43 & $36.8 \pm 4.4$ & 22 \\
\hline 13 & $532 \pm 120$ & 72 & $8.0 \pm 2.2$ & 31 & $38.5 \pm 3.3$ & 29 \\
\hline 14 & $527 \pm 125$ & 53 & $9.4 \pm 3.0$ & 28 & $36.1 \pm 7.3$ & 21 \\
\hline 15 & $492 \pm 115$ & 63 & $8.3 \pm 2.5$ & 45 & $39.9 \pm 3.6$ & 36 \\
\hline
\end{tabular}

$\mathrm{s}=$ standard deviation of mean. 

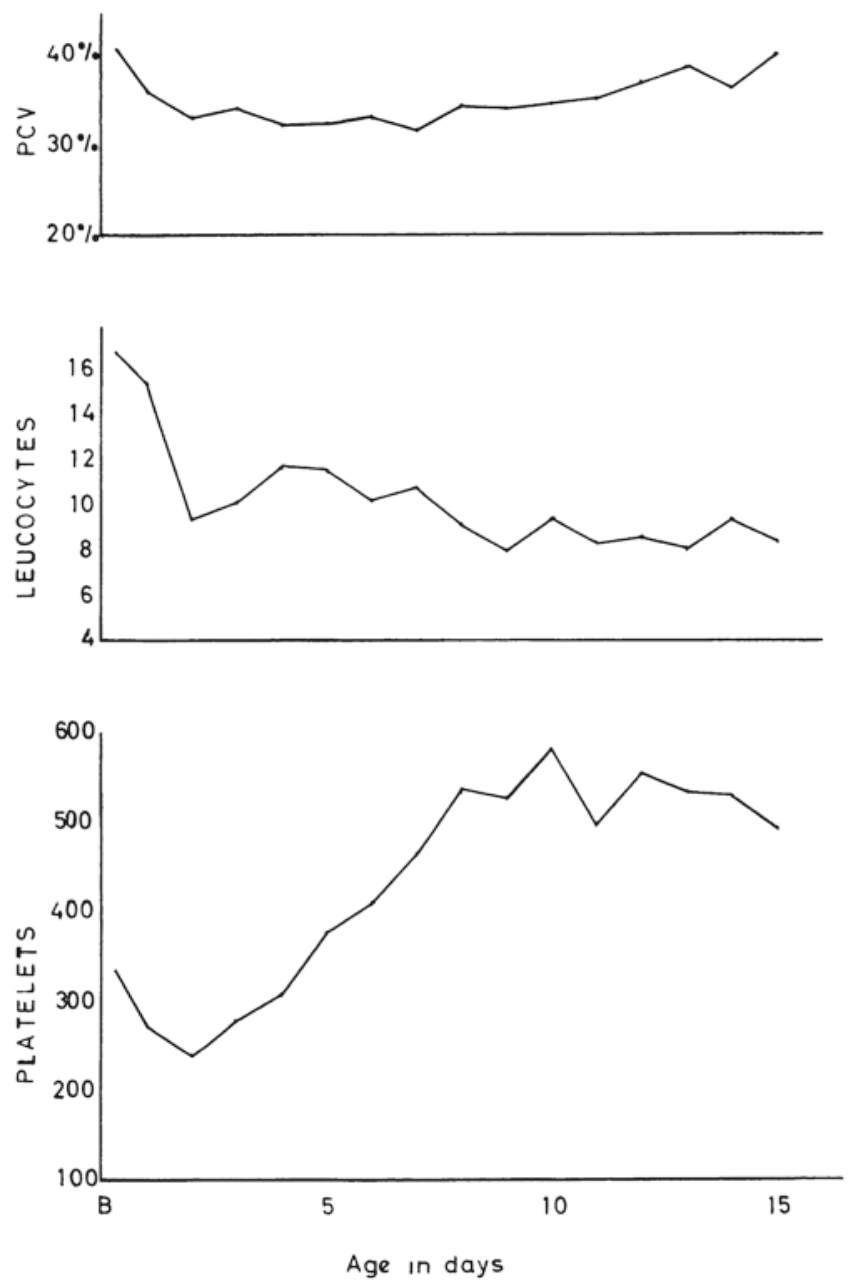

Figure 1. Platelet number, total leucocyte number and packed red cell volume (PCV) in normal piglets during the first 15 days of life.

The platelet and leucocyte numbers are given in thousand $/ \mathrm{mm}^{3}$.

In the whole period only 3 counts out of 789 observed were lower than 4.5 , and after the 2nd day 3 only were higher than 20.0 .

The PCV was highest at birth (Table 1, Fig. 1), ranging from 25 to $52 \%$, with a mean of $40.8 \%$. It decreased during the first 2 days to $32.9 \%$. On the 7 th day the mean was $31.5 \%$, increasing during the next week to $39.9 \%$ on the 15 th day.

The 483 observations made from the 2nd to the 15th day all except 14 ranged from 25 to $45 \%$. Six were higher than $45 \%$ and 8 were lower than $25 \%$. 


\section{DISCUSSION}

The determination of platelet number may be influenced in several ways. When blood is taken, the pipette has to be filled at once and the blood mixed with the anticoagulant without delay. If not and the blood clotting has initiated, platelets are lost, and the platelet count will be too low. During the first 2-3 days the best samples could not always be obtained. The lowest counts observed at this time therefore may be too low. Later the samples could be obtained more easily, because the piglets were more active and had learned to sleep under the heating lamp - both resulting in a better blood circulation. In addition the adhesive plaster, which was put on the ear to stop bleeding, often caused a slight hyperemia.

If the piglets are exposed to infectious diseases, this may influence the platelet number in the acute stage: A litter of 10, not included in the material studied in the present report, had normal platelet counts the first week of life (Lie, unpublished). From the 9th to 10th day they suffered from a severe infection affecting the respiratory organs. Three of them died 16 days old. In the piglets of this litter the platelets dropped from 500-600 on the 8th day to below 200 on the 15th day. The 3 piglets that died had counts $60-100$ the last day before death.

Contrary to the platelet number, the leucocyte number seems to increase during the first day. This assumption is supported by Luke's (1953) investigations on 53 newborn pigs. The same has been found in children, where the highest counts are obtained at $24 \mathrm{hrs}$. of age (Wintrobe 1961).

For the rest of the period the leucocyte number mainly ranged from 4.5 to 20.0 , which corresponds with observations made by others. Gardiner et al. (1953) found variations from 5.4 to 23.0 in blood samples taken at 1,8 and 15 days of age from 6 litters. Venn (1944) found variations from 5 to 11 in 2 litters at the age of 5 to 17 days. Frazer (1938) made 31 observations at different times within the first 2 weeks, the counts ranging from 5 to 27 , and Schalm (1961) found variations from 5.6 to 19.1 in a litter of 9 during the first 10 days after birth.

If the piglets get no supply of iron, the PCV will be gradually reduced (Kernkamp 1932). He investigated the blood picture of piglets kept on concrete without supply of iron, and of piglets kept on loam. The mean hemoglobin $(\mathrm{g} / 100 \mathrm{ml})$ for the piglets kept on loam was 11,785 at birth, 8,119 at 5 days of age and 
11,060 at 19 days of age, whereas for the piglets kept on concrete the numbers were $9,586,5,750$ and 4,428 respectively.

Own investigation (unpublished) on a litter of 12, kept on concrete without any supply of iron, revealed a reduction of PCV from a mean of $47.5 \%$ at birth to $29.8 \%$ at 7 days of age and $19.2 \%$ at 17 days of age. These values are considerably lower than those observed in the present normal material.

\section{AGKNOWLEDGMENT}

I am very grateful to Professor Johs. L. Flatla for his never failing interest and helpful advice, and for the facilities provided by him; and to Dr. Mikael Brænd for helpful criticism and advice.

I also wish to thank Mr. Lars Bjørsrud for his assistance by collecting the blood samples.

\section{REFERENCES}

Frazer, A. C.: A study of the blood of pigs. Brit. vet. J. 1938, 94, 3-21. Gardiner, M. R., W. L. Sippel \& W. C. McCornick: The blood picture in newborn pigs. Amer. J. vet. Res. 1953, 14, 68-71.

Kernkamp, H. C. H.: The blood picture of pigs kept under conditions favorable to the production and to the prevention of so-called "Anemia of suckling pigs". Minnesota agric. exp. Sta. tech. Bull. $1932,86,32 \mathrm{pp}$.

Luke, D.: The differential leucocyte count in the normal pig. J. comp. Path. 1953, 63, 346-354.

Nygaard, K. K.: Direct method of counting platelets in oxalated plasma. Proc. Mayo Clin. 1933, 8, 365-370.

Schalm, O. W.: Veterinary Hematology. Lea \& Febiger, Philadelphia 1961 , p. 190.

Venn, J. A. J.: Variation in the leucocyte count in the pig. J. comp. Path. 1944, 54, 172-178.

Wintrobe, M. M.: Clinical Hematology, 5th Ed. Lea \& Febiger, Philadelphia 1961, p. 244.

\section{SUMMARY}

Number of platelets, leucocytes and packed red cell volume (PCV) have been determined in normal piglets during the first 2 weeks of life.

A mean platelet count of $337 \pm 79$ at birth decreased during the first 2 days to $241 \pm 48$, followed by increasing numbers the next week to a maximum of $578 \pm 128$ at 10 days after birth. Then a slight decrease to $492 \pm 115$ on the 15 th day was observed.

The leucocyte counts were highest the first $30 \mathrm{hrs}$. of life, the mean count being 16.9. During this period, however, there was as wide a range as from 3.6 to 46.3 . For the rest of the period the mean varied from 8.0 to 11.8 , the counts ranging from 4.5 to 20.0 . 
The mean PCV, which was highest at birth, decreased from a mean of $40.8 \pm 6.1$ to $32.9 \pm 5.0$ during the first 2 days. At 7 days of age the mean was $31.5 \pm 3.8$ but increased during the following week to $39.9 \pm 3.6$ on the 15 th day.

\section{ZUSAMMENFASSUNG}

Die Thrombozytenzahl, Leukozytenzahl und PCV (Hämatokrit\%) der normalen Ferkel in den ersten zwei Wochen nach Geburt.

Eine Durchschnittzahl der Thrombozyten von $337 \pm 79$ gleich nach der Geburt verminderte sich die zwei ersten Tage bis $241 \pm 48$ am zweiten Tag, wonach eine Vermehrung bis ein Maximum von $578 \pm 128$ am 10. Tag statt fand. Am 15. Tag war die Zahl bis $492 \pm 115$ gesunken.

Die grösste Leukozytenzahl wurde innerhalb der ersten 30 Stunden observiert. Die Durchschnittzahl war 16,9, die Weite der Variationen jedoch so gross wie 3,6-46,3 in dieser Periode.

Vom zweiten Tag ab lag die Durchschnittzahl zwischen 8,0-11,8 die ganze Periode hindurch. Die einzelnen Zählungen lagen hauptsächlich zwischen 4,5-20,0.

Das PCV war 40,8 $\pm 6,1$ gleich nach der Geburt, hatte schon am zweiten Tag bis zum 32,9 $\pm 5,0$ abgenommen und war am siebsten Tag $31,5 \pm 3,8$. Die nächste Woche nahm es aber zu und war $39,3 \pm 3,6$ am 15. Tag.

\section{SAMMENDRAG}

Antall blodplater og leukocyter, samt PCV (hematokrit\%) hos normale smågriser de to første leveuker.

Like etter fødsel ble det funnet et middeltall av thrombocyter på $337 \pm 79$, som sank til $241 \pm 48$ i l $\varnothing$ pet av de to f $\varnothing$ rste dager. Deretter var det en stigning de følgende dager til et maksimum $578 \pm 128$ den tiende dagen. Tallet avtok så svakt til $492 \pm 115$ den 15. dagen.

Leukocyttallet var høyest de første 30 timene. Middeltallet var da 16,9 , men variasjonsbredden var stor, 3,6-46,3, på denne tiden. Fra den andre dagen og ut perioden svingte middeltallet mellem $8,0-11,8$, mens de enkelte tall, med få unntak, lå mellem 4,5-20,0.

PGV minket fra 40,8 $\pm 6,1$ like etter fødsel til 32,9 $\pm 5,0$ den andre dagen. Lavest verdi, $31,5 \pm 3,8$, ble funnet syvende dag. Den steg så i slutten av perioden til $39,9 \pm 3,6$ den 15 . dagen.

(Received January 10, 1968). 